\title{
ASSESSING SOCIAL SUPPORT AND EMOTIONALITY OF STUDENTS IN PROBLEM SOLVING
}

\author{
Intan Laelatul Mubarokah, Widodo Winarso, Mumun Munawaroh \\ Department of Mathematics, Faculty Tarbiyah and Teacher Science \\ IAIN Syekh Nurjati Cirebon \\ intanlm17@gmail.com
}

\begin{abstract}
Abstrak
Penelitian ini bertujuan untuk mengetahui hubungan antara social support dengan emosionalitas siswa dalam pemecahan masalah matematika. Penelitian ini merupakan penelitian kuantitatif dengan menggunakan desain korelasional. Teknik pengambilan sampel dengan menggunakan purposive sampling dengan subyek penelitiannya siswa kelas XI IPA 2 sebanyak 39 siswa dan kelas XI IPA 3 sebanyak 40 siswa di MAN 2 Majalengka. Teknik pengumpulan data menggunakan angket pernyataan terhadap social support dan emosionalitas siswa. Hasil dari penelitian ini menunjukkan bahwa Besaran social support yang diberikan terhadap siswa sebesar $81 \%$ dalam kategori sangat kuat dan kondisi emosionalitas siswa sebesar $81 \%$ dalam kategori sangat kuat. Selain itu, Hasil pengujian hipotesis menunjukan bahwa t_hitung 5,527 dengan nilai signifikansi 5,527>2,000. Maka $\mathrm{H}_{\mathrm{o}}$ ditolak dan $\mathrm{H}_{\mathrm{a}}$ diterima, sehingga dapat maknai bahwa social support berhubungan dengan emosionalitas siswa dalam pemecahan masalah matematika.
\end{abstract}

Kata kunci: Social support, emosionalitas siwa, pemecahan masalah matematika

\begin{abstract}
This study aims to determine the relationship between social support and student emotionality in solving mathematical problems. This research is a quantitative study using correlational design. The sampling technique used was purposive sampling with the subjects of the XI IPA 2 class as many as 39 students and XI IPA 3 classes as many as 40 students in MAN 2 Majalengka. The data collection technique uses statement questionnaires for students' social support and emotionality. The results of this study indicate that the amount of social support given to students is $81 \%$ in the very strong category and the emotionality of students is $81 \%$ in the very strong category. In addition, the results of hypothesis testing indicate that $t$ count is 5.527 with a significance value of $5.527>2,000$. Then $H_{O}$ is rejected and $\mathrm{Ha}$ is accepted so that it can mean that social support is related to student emotionality in mathematical problems solving.
\end{abstract}

Keyword: Social support, student emotionality, mathematical problem solving

Sitasi: Mubarokah, L.I. Winarso, W. Munawarah,M. 2019. Assessing Social Support and Emotionality of Students In Problem Solving . Matematika dan Pembelajaran, 7(1), $35-49$. 


\section{INTRODUCTION}

This school was established to carry out the task of realizing national aspirations, national ideals, and educational goals. With all seriousness, the school must carry out its duties to realize the goals of education. As expressed by Sumadi (2004) that schooling can guide students to become private Pancasila citizens, based on God Almighty, aware, have a community and be able to process the environment, and can become human beings who can develop themselves optimally, according to their intelligence, talents and interests, so that they have a balanced personality and entrepreneurs and are responsible for the welfare of society and the state

Education is inseparable from human resources, because of the higher the quality of human resources, the better the quality of education. One effort to create quality human resources is through the implementation of education. According to Yuliana (2017) that education plays an important role in preparing qualified human resources and able to compete in the development of science and technology. So that education must be carried out as well as possible to get maximum results. So from that education has a very decisive role for individual development, because human education acquires knowledge and intelligence and can develop abilities, attitudes, and behavior (Carmeli, 2003).

According to Yashinta \& Gregoria (2015) in the world of education, one of the subjects that has an important role in mathematics. Mathematics is the basis for other subjects (Wheatley, 1991). Therefore, mathematics has always been a subject that has received special attention at all levels of education. In studying mathematics students are required to actively practice, in addition, students are expected to be able to control internal and external elements that influence mathematics learning. The learning approaches and methods used. In mathematics learning students are also expected to be able to connect mathematics in real life and other sciences (Britton, Huntley, Jacobs \& Weinberg, 1999).

Mathematics is a subject that must be given at every level of education as stated in Law No. 23 of 2003 concerning the National Education System, Article 
37 paragraph 1 which states that "primary and secondary education curriculum must contain mathematics education". In addition, the need for mathematics in the world of education is very important. According to Sumirat (2014: 24), one of the goals of mathematics education is the formation of student attitudes, therefore it is very appropriate in the process of learning mathematics to pay attention to students' attitudes towards mathematics. this is important because a positive attitude towards mathematics will be positively correlated with mathematics learning achievement (Ryan \& Pintrich, 1997).

One of the objectives of learning mathematics is that students have the ability to understand mathematical concepts, explain the interrelationships between concepts, and apply concepts and algorithms accurately, efficiently, and precisely in communicating ideas with symbols, tables, diagrams or other media to clarify the problem (Cross, Woods \& Schweingruber, 2009). Mathematics lessons can also guide students to be more logical in determining problems and students are led to often use deductive stages in problems solving (Stigler \& Hiebert, 1997).

The fundamental reason teachers must design learning well is to be able to achieve the desired educational goals. In general, according to Muhammad Chandra (2015), the purpose of education is any form of activity that contributes to the maximum functioning of the supporting components of the education system. Not only the teacher as a facilitator who becomes the main support, but the emotional level in students is the most important component in the process of achieving learning goals.

In line with this, the research conducted by Rahmasari (2012) about one's abilities is determined by the intelligence they have. Most of the human resources in developing countries including Indonesia still have poor emotional intelligence. This is one of the causes of the weak quality of human resources in Indonesia (Mangkunegara, 2010). Even though the research results of Goleman (2003) show that the greatest ability that influences a person's success in work is empathy, selfdiscipline, and initiative known as emotional intelligence. According to Charles Schreiber, the success of one's life is determined to be $15 \%$ formal, while $85 \%$ is determined by his mental attitude/personality (Mangkunegara, 2010). 
Intelligence controls emotionality is very important in life because it involves the ability to control emotions and adapt to the environment (Winarso \& Supriady, 2016). According to Goleman (2002), emotional intelligence is a person's ability to regulate his emotional life with intelligence; maintain emotional harmony and disclosure through self-awareness skills, self-control, self-motivation, social skills, and empathy.

For a student, the intelligence to control emotions is very important especially for controlling emotions that are still explosive. While mood coordination is the core of good social relations. When someone is good at adjusting to the mood of another individual or can empathize, people will have a good level of emotionality, he will be more adaptable in social and environmental interactions (Ball \& Vincent, 2001).

Therefore, students who carry out learning activities must get motivated. Learning motivation can arise due to intrinsic and extrinsic factors (Syamarro, Saluky \& Winarso, 2015). The intrinsic factor is the desire and desire to succeed, the encouragement of learning needs, expectations, and ideals. Extrinsic factors are the existence of awards, a conducive learning environment, and interesting learning activities (Uno, 2009). Social support is included in environmental factors that can influence learning motivation. According to Dimatteo (1991) social support as support or assistance that comes from other people such as friends, neighbors, coworkers, and other people. Then according to Pierce in Kail \& Cavanaugh (2000) defines social support as a source of emotional, informational, or mentoring provided by people around individuals to deal with every problem and crisis that occurs in everyday life. In addition, sources of social support can also be obtained from professional circles and social support groups.

According to Sarafino (2006), there are five forms of social support, namely emotional support, award support, instrumental support, information support, and group support. In this study, social support came from parents, teachers, and peers. The existence of social support will give a feeling of comfort, respect, and attention for students so that it will lead to motivation to study harder. 
Each individual has a problem, on a narrow or broad scale, simple or complex. Individual success is determined by its creativity in solving problems. Students consider mathematics difficult and not easily mastered and abstract mathematical characteristics so students consider mathematics to be a frightening specter. Students feel less having confidence in solving mathematical problems, rarely arises curiosity when in learning, lack of enthusiasm when learning does not want to share with others, these attitudes are the reason why students have difficulty solving mathematical problems.

According to Sujono (1998), a mathematical problem can be described as a 'challenge' if the solution requires creativity, understanding, original thinking or imagination. A question or math problem is said to be a problem if the solution requires creativity, understanding and thought or imagination of everyone who faces the problem.

In fact, for all levels of school, many students are negative towards mathematics, students consider mathematics as a field of study that is difficult to learn (Kamsari \& Winarso, 2018). They are afraid of mathematics. Of course, the negative views or attitudes influence students 'ways of learning mathematics, therefore it is assumed that students' negative views on mathematics, is one indicator of why students cannot solve mathematical problems

But for those who think mathematics is fun, it will grow mathematically in individuals to learn mathematics and be optimistic in solving challenging problems in mathematics learning. Conversely, for those who consider mathematics as a difficult lesson, then the individual will be pessimistic in solving mathematical problems. These attitudes will certainly influence the way students solve mathematical problems

Solving a mathematical problem requires students to relate to an unknown situation through thinking flexibly and creatively (Mousoulides et al., 2007). In the process of learning mathematics, a teacher usually presents a problem in the form of questions and requires answers or tasks that must be completed. But it sometimes makes students feel difficult. So to deal with situations like this, the task of a teacher is to know in advance the characteristics of their students. If a teacher already knows 
the characteristics of his students, then he knows how for students to solve mathematical problems effectively and systematically.

\section{METHOD}

This type of research is a type of quantitative research that is correlational in nature that aims to find information about the relationship between various variables, namely the relationship between social support and student emotions in solving mathematical problems. This research was conducted in MAN 2 Majalengka with a population of 198 students who were affordable in the XI IPA class.

The sample in this study was determined by using a purposive sampling technique, where the sampling technique used by researchers had certain considerations in sampling or determining samples for specific purposes, only those who were experts should give consideration to taking the necessary samples. Consideration was taken from experts here, namely the mathematics teacher of class XI of MAN 2 Majalengka so that the subjects of this study were students of class XI IPA 2 as many as 39 students and XI IPA 3 as many as 40 students .

This study uses a research design with correlational design. According to Sukardi (2009: 166), correlational research is a study that involves the act of collecting data to determine, is there a relationship and the level of relationship between two or more variables. The purpose of correlation research design is to determine whether there is a relationship between the two variables of this study. This study has two variables, namely social support as an independent variable (X), and student emotionality in solving mathematical problems as a dependent variable (Y). which will be examined in this study can be described as follows, According to Sugiyono (2017: 42). 


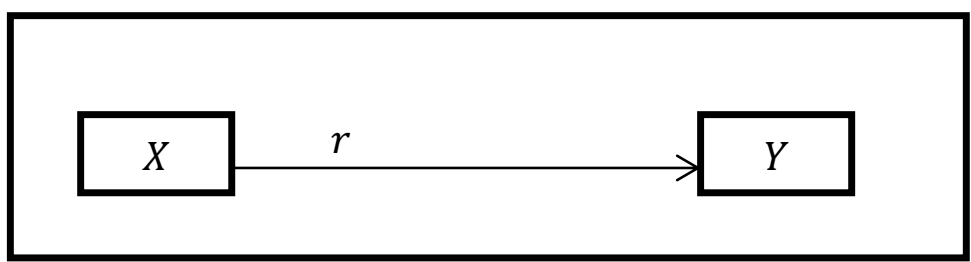

Figure 1. Variable Interactions

Explanation :

$\begin{array}{ll}\mathrm{X} & \text { : Social support } \\ \mathrm{Y} & \text { : Emotionality in solving mathematical problems } \\ \mathrm{r} & \text { : Relationship }\end{array}$

In this study used one data collection technique, namely questionnaire. Questionnaires or questionnaires are distributed to students, namely questionnaires about social support with the emotionality of students with researchers explaining in advance how the process works to students. The questionnaire data aims to determine the relationship between social support and student emotionality in solving mathematical problems. The questionnaire that researchers make is inseparable from indicators of social support or independent, namely: empathy, caring, attention, respect, being accepted by others, positive assessment of students, direct assistance in the form of material, direct assistance in the form of action, helping to solve problems, giving advice or solutions, and provide guidance, participate in group activities, and provide a sense of togetherness in groups (Sarason, Levine, Basham \& Sarason, 1983). While the questionnaire of the indicators of student emotionality (dependent), namely: recognize and feel emotions themselves, understand the causes that arise, recognize the influence of feelings on actions, be tolerant of frustration, be able to control aggressive behavior that can damage themselves and others, have positive feelings with yourself and the environment, able to control yourself, be optimistic in dealing with problems, be able to focus on the task given, be able to accept the point of view of others, have the nature of empathy or sensitivity to others, able to listen to others, understand the importance of building relationships with other people, have attention to the interests of others, and are mature and tolerant (Waller, Tellegen, McDonald, \& 
Lykken, 1996).

Before the data is analyzed, the normality test, the homogeneity test, is carried out. After that the data is tested using a correlation test, then after the correlation index number is known, then the significance (meaningfulness/significance) of the relationship X with $\mathrm{Y}$ or social support with the emotionality of students is sought. If $t_{\text {count }}>t_{\text {table }}$ then Ho is rejected and Ha is accepted. Then there is a relationship between $\mathrm{x}$ and $\mathrm{y}$ variables, and vice versa

\section{RESULTS AND DISCUSSION}

\section{Social Support Conditions for Students}

According to Papalia \& Olds (1995) states that giving social support from people that means around the life of students gives the greatest contribution in increasing student self-esteem. Whereas according to Orford (1992) social support works with the aim to minimize the influence of stresses or stress experienced by students when learning mathematics at school. In other words, if there is no pressure or stress, social support has no effect. In accordance with Wills in Orford (1992) which states that the form of social support needed by individuals with low selfacceptance, requires emotional social support and social groups. Given this, social support plays an important role in the lives of students who experience problems in mathematics learning. In line with these conditions, Dimatteo (1991) emphasizes more on social support as support that comes from other people, such as friends of study, family and environment.

Furthermore, Sarason, Levine, Basham \& Sarason in Orford (1992) stated that social support itself has several components, namely instrumental support, emotional support, esteem support, informational support, and social companion support. In line with this opinion, in this study, the instrument support developed by the author for the measurement of social support students adopted the conceptual definition according to Sarafino (2006) that there are five forms of social support: emotional support, award support, instrumental support, information support, and group support. The research data shows the condition of social support students in 
MAN 2 Majalengka is as follows.

Table 1. The Proportion of Social Support Students

\begin{tabular}{|l|c|c|}
\hline \multicolumn{1}{|c|}{ Indicator } & Percentage (\%) & Category \\
\hline Empathy & 88 & Very strong \\
\hline Concern & 81 & Very strong \\
\hline Attention & 80 & Strong \\
\hline Appreciate & 77 & Strong \\
\hline Accepted by others & 81 & Very strong \\
\hline Positive assessment of students & 79 & Strong \\
\hline Direct assistance in the form of material & 78 & Strong \\
\hline Direct assistance in the form of action & 77 & Strong \\
\hline Helping problems solve & 83 & Very strong \\
\hline $\begin{array}{l}\text { Provide advice or solutions, and provide } \\
\text { guidance }\end{array}$ & 79 & Strong \\
\hline Participate in group activities & 85 & Very strong \\
\hline Giving a sense of togetherness in the group & 83 & Very strong \\
\hline \multicolumn{2}{|c|}{ Percentage Average: 81\% (Very strong) } \\
\hline
\end{tabular}

Based on the table above, the percentage of the 12 social support indicators, the lowest percentage is known to be $77 \%$, namely the indicator of respect and direct assistance in the form of action. While the highest percentage is $88 \%$ on the empathy indicator. The percentage of the 12 indicators is $81 \%$ included in the very strong category.

\section{Student Emotionality Conditions in Mathematical Problems Solving}

Students' emotionality in mathematical problems solving, namely the ability to motivate themselves, overcome frustration, control heart pressure, regulate mood, empathy and the ability to work together in the process of answering mathematics (Goleman, 2004).

Whereas the mathematical problem in this paper is an unknown entity and needs to be solved, related to mathematics in school. Solving a mathematical 
problem requires students to relate to an unknown situation through thinking flexibly and creatively (Mousoulides et al., 2007). In the process of learning mathematics in schools, teachers usually present mathematical problems to be solved by students in the form of questions that require answers, or tasks that must be completed. Gagne in Orton, (1992) suggests that problem-solving is the highest form of learning. Thus it can be said that all activities learn the rules, techniques, and contents of the lesson so that they can understand mathematics so that students are able to solve mathematical problems by conditioning their emotionality well.

By referring to these two contexts, the researcher uses and develops these indicators in measuring feelings (affect) that encourage students to respond or behave towards stimuli, both from within and from outside themselves as support in solving mathematical problems. The results of the study show the emotionality conditions of students in solving mathematical problems as follows.

Table 2. The Proportion of Student Emotionality in Mathematical Problems

Solving

\begin{tabular}{|c|c|c|}
\hline Indicator & Percentage (\%) & Category \\
\hline Getting to know and feel your own emotions & 83 & Very strong \\
\hline $\begin{array}{l}\text { Understanding the cause of feelings that } \\
\text { arise }\end{array}$ & 84 & Very strong \\
\hline Knowing the effect of feelings on actions & 80 & Strong \\
\hline Be tolerant of frustration & 71 & Strong \\
\hline $\begin{array}{l}\text { Able to control aggressive behavior that can } \\
\text { damage yourself and others }\end{array}$ & 84 & Very strong \\
\hline $\begin{array}{l}\text { Having positive feelings with yourself and } \\
\text { the environment }\end{array}$ & 83 & Very strong \\
\hline Able to control yourself & 79 & Strong \\
\hline Be optimistic in dealing with problems & 80 & Strong \\
\hline Able to focus on the task given & 90 & Very strong \\
\hline Able to accept other people's perspectives & 84 & Very strong \\
\hline $\begin{array}{l}\text { Have the nature of empathy or sensitivity to } \\
\text { others }\end{array}$ & 80 & Strong \\
\hline Able to listen to other people & 79 & Strong \\
\hline $\begin{array}{l}\text { Understanding the importance of building } \\
\text { relationships with others }\end{array}$ & 80 & Strong \\
\hline Having attention to the interests of others & 83 & Very strong \\
\hline Be mature and tolerant & 77 & Strong \\
\hline
\end{tabular}


Based on the table above, the research data from 15 student emotionality indicators in mathematical problems solving is known to be the lowest percentage of $71 \%$, which is the indicator of being tolerant of frustration. While the highest percentage is $90 \%$ occurs in the indicator able to focus on the task given. As a whole, the percentage of the 15 indicators is $81 \%$ included in the very strong category.

\section{The Relationship Between Social Support and Student Emotionality in Students' Mathematical Problems Solving}

To analyze the relationship between social support and student emotionality in mathematical problem solving using Pearson Correlation analysis. The data from the hypothesis test results are obtained as follows.

Table 3. Correlation Test Results

\begin{tabular}{|ll|r|r|}
\hline & \multicolumn{1}{|c|}{$\begin{array}{c}\text { Social } \\
\text { support }\end{array}$} & $\begin{array}{c}\text { Student } \\
\text { emotionality }\end{array}$ \\
\hline Social & Pearson Correlation & 1 &, 533 \\
support & Sig. (2-tailed) & 79 &, 000 \\
& $\mathrm{~N}$ &, 533 & 79 \\
\hline Student & Pearson Correlation &, 000 & 1 \\
emotionality & Sig. (2-tailed) & 79 & 79 \\
& $\mathrm{~N}$ & & \\
\hline
\end{tabular}

Based on the correlation test results, obtained a significant value of 0,000 because a significant value is smaller than $0.05(0,000<0,050)$, then Ho is rejected and $\mathrm{Ha}$ is accepted, meaning that there is a significant relationship between social support with the emotionality of students in mathematical problems solving. While the output of the correlation of the Pearson Correlation value is 0.533 . This correlation value is between $0.40-0.599$, so the effect is a medium correlation. Then based on hypothesis testing using the $r$ test, then the value of $r=k n o w n ~ r_{\text {count }}$ is 5.527 and $\mathrm{r}_{\text {tabel }}$ is $2,000(5.527>2,000)$. Then the decision is taken that $\mathrm{H}_{\mathrm{O}}$ is rejected and $\mathrm{H}_{\mathrm{a}}$ is accepted. based on the data from the research, the research hypothesis can be accepted that social support has a relationship with student 
emotionality in solving mathematical problems.

The results of this study can be interpreted that when students get high social support from their environment, students will be able to control their emotions well and students will also be excited when faced with solving mathematical problems. In addition to providing good social support has an impact on the ability to know and respond to their own feelings well and can read and handle other people's feelings effectively. This condition is in line with the results of research by Fani Kumalasari (2012) which states that there is a relationship between social support and adjustment.

The research has limitations because it is only limited to mathematics subjects in students of class XI science in MAN 2 Majalengka. So it is necessary to develop further research, not only in dealing with student emotionality but using relationships with other dependent variables so that students are able to solve problems properly and correctly.

\section{CONCLUSION}

Based on the objectives of the research and discussion that have been adjusted in the previous chapters regarding the relationship between social support for student emotionality in solving mathematical problems in class XI IPA MAN 2 Majalengka, the conclusion is that the first questionnaire of social support is obtained by the average of all indicators $81 \%$ in the very strong category. And the second questionnaire of student emotionality obtained an average score of all indicators of $81 \%$ in the very strong category. Then the results of the study showed that there was a relationship between social support and student emotionality in solving mathematical problems. This is indicated by the results of the correlation test significant value of 0,000 because a significant value is smaller than 0.05 $(0,000<0,050)$, then Ho is rejected and $\mathrm{Ha}$ is accepted, meaning that there is a relationship between social support and student emotionality. With the results of the output correlations of the Pearson Correlation value between social support and the student emotionality of 0.533 , this correlation value is between $0.40-0.599$ then 
the effect is a medium correlation. Then it can be concluded that the relationship between social support and emotionality of students has a moderate correlation. Also based on the hypothesis by using a t-test, then the value of $\mathrm{t}=$ is known to $\mathrm{t}_{\text {count }}$ as $5.527 t_{\text {table }} 2,000(5.527>2,000)$ then $\mathrm{H}_{\mathrm{O}}$ is rejected and $\mathrm{H}_{\mathrm{a}}$ is accepted, so it can be concluded that social support variables relate to student emotionality variables

Based on the research that has been done by the author and discussion of the results of the research, the author suggests the first to practitioners, when students get high social support from their surroundings, students will be able to control their emotions and students will be excited when faced with solving mathematical problems. support, students are able to know and respond to their own feelings well and are able to read and deal with other people's feelings effectively.

\section{REFERENCE}

Ball, S., \& Vincent, C. (2001). New Class Relations in Education: The Strategies of The 'Fearful'middle Classes. In Sociology of Education Today (pp. 180195). Palgrave Macmillan, London.

Britton, E., Huntley, M. A., Jacobs, G., \& Weinberg, A. S. (1999). Connecting Mathematics and Science to Workplace Contexts: A Guide to Curriculum Materials. Corwin Press, Inc., A Sage Publications Company, 2455 Teller Road, Thousand Oaks, CA 91320-5323.

Carmeli, A. (2003). The Relationship Between Emotional Intelligence and Work Attitudes, Behavior and Outcomes: An Examination Among Senior Managers. Journal of managerial Psychology, 18(8), 788-813.

Cross, C. T., Woods, T. A., \& Schweingruber, H. E. (2009). Mathematics Learning in Early Childhood: Paths Toward Excellence and Equity. National Academies Press.

Di Matteo, M. R. (1991). The Psychology of Health, Illness, and Medical care. Pasific Grove, California: Brooks.

DiMatteo, M. R. (1991). The Psychology of Health, Illness, and Medical Care. Pasific Grove, California: Brooks / Cole Publishing Company

Goleman, D. (2003). Working with Emotional Intelligence. Jakarta: PT. Gramedia Pustaka Utama.

Goleman, D. (2009). Emotional intelligence; kecerdasan emosional, mengapa EI lebih penting dari IQ. Jakarta: PT. Gramedia Pustaka Utama.

Gumilar, M. C. (2015). Penerapan Pendekatan Inkuiri Untuk Meningkatkan Hasil Belajar Siswa Pada Mata Pelajaran IPA Kelas V Sekolah Dasar (Doctoral dissertation, Universitas Pendidikan Indonesia). 
Kamsari, K., \& Winarso, W. (2018). Implikasi Tingkat Kecerdasan Logika Matematika Siswa terhadap Pemecahan Masalah Matematika. Edu Sains: Jurnal Pendidikan Sains \& Matematika, 6(1), 44-52.

Kumalasari, F., \& Ahyani, L. N. (2012). Hubungan antara dukungan sosial dengan penyesuaian diri remaja di panti asuhan. Jurnal Psikologi: PITUTUR, 1(1), $19-28$.

Mangkunegara, A. P. (2010). Evaluasi Kinerja SDM. In Evaluasi Kinerja SDM (p. 76). Bandung: Refika Aditama

Mousoulides, N., Sriraman, B., \& Christou, C. (2007). From problem solving to modelling. Education, 12(1), 23-47.

Orford. (1992). Community Psychology: Theory and practice. John-Wiley and Son.

Orton, A. (1992). Learning mathematics: Issues, theory and practice. Great Britain: Redwood Books.

Papalia, D. E., \& Olds, S. W. (1981). Human development. McGraw-Hill Companies.

Rahmasari, L. (2016). Pengaruh Kecerdasan Intelektual, Kecerdasan Emosi dan Kecerdasan Spiritual Terhadap Kinerja Karyawan. Majalah Ilmiah Informatika, 3(1).1-20

Rice, F. P., \& Vestal, L. B. (1998). Human development: A life-span approach. American: Wadsworth

Ryan, A. M., \& Pintrich, P. R. (1997). " Should I ask for help?" The role of motivation and attitudes in adolescents' help seeking in math class. Journal of educational psychology, 89(2), 329.

Sarafino, E. P., \& Smith, T. W. (2014). Health psychology: Biopsychosocial interactions. John Wiley \& Sons.

Sarafino, Edward.P. (2002). Health Psychology: biopsychosocial interaction. (4thedition). New York.

Sarason, I. G., Levine, H. M., Basham, R. B., \& Sarason, B. R. (1983). Assessing social support: The social support questionnaire. Journal of personality and social psychology, 44(1), 127.

Stigler, J., \& Hiebert, J. (1997). Understanding and improving classroom mathematics instruction: An overview of the TIMSS video study. In ACER National Conference 1997 (pp. 52-65).

Sugiyono, P. (2011). Metodologi Penelitian Kuantitatif Kualitatif Dan R\&D. Alpabeta, Bandung.

Sujono. (1998). Pengajaran Matematika untuk Sekolah Menengah. Jakarta: Departemen Pendidikan dan Kebudayaan

Sukardi. (2009). Metodologi Penelitian Pendidikan(Kompetensi dan Praktiknya). Jakarta: Bumi Aksara.

Sumadi, S. (2004). Psikologi Pendidikan. Bandung: Pustaka Setia

Sumirat, L. A. (2013). Efektifitas strategi pembelajaran kooperatif tipe think-talk-write (TTW) terhadap kemampuan komunikasi dan disposisi matematis siswa (Doctoral dissertation, Universitas Terbuka).

Syamarro, N., Saluky, S., \& Winarso, W. (2015). Pengaruh Motivasi Dan Persepsi Siswa Pada Matematika Terhadap Prestasi Belajar Matematika Siswa Kelas VIII Di Mts Al-hidayah Dukupuntang Kabupaten Cirebon (Pokok Bahasan Kubus Dan 
Mubarokah, L.I. Winarso, W. Munawarah, M. 2019. Assessing social support and emotionality... Matematika dan Pembelajaran, 7(1), $\underline{49}$ of 49

Balok). Eduma: Mathematics Education Learning and Teaching, 4(2).105-111

Uno, H. B. (2009). Teori motivasi dan Pengukurannya (Analisis di Bidang Pendidikan). Jakarta: Bumi Aksara

Waller, N. G., Tellegen, A., McDonald, R. P., \& Lykken, D. T. (1996). Exploring nonlinear models in personality assessment: Development and preliminary validation of a negative emotionality scale. Journal of Personality, 64(3), 545-576.

Wheatley, G. H. (1991). Constructivist perspectives on science and mathematics learning. Science education, 75(1), 9-21.

Winarso, W., \& Supriady, D. (2016). Menilai Prestasi Belajar melalui Penguatan Self Regulated Learning dan Kecerdasan Emosional Siswa pada Pembelajaran Matematika. Jurnal Didaktik Matematika, 3(2).

Yashinta, A. P., \& Ariyanti, G. (2015). Pengaruh Kecerdasan Emosional Terhadap Prestasi Dan Sikap Belajar Matematika Siswa Dalam Pembelajaran Ekspositori. Educatio Vitae, 2(1).1-10

Yuliana, R. (2017). Pengembangan Perangkat Pembelajaran Dengan Pendekatan PMRI pada Materi Bangun Ruang Sisi Lengkung Untuk SMP Kelas IX. Jurnal Pendidikan Matematika-S1, 6(1), 60-67. 